\title{
Potensi dan Strategi Pengembangan Wakaf Uang di Indonesia
}

\author{
Haniah Lubis \\ Universitas Islam Negeri Sultan Syarif Kasim Riau \\ haniah.lubis@uin-suska.ac.id
}

\begin{abstract}
Abstrak
Sebagai salah satu instrumen wakaf produktif, wakaf uang merupakan hal yang masih baru di Indonesia. Peluang untuk wakaf uang ada setelah Majelis Ulama Indonesia mengeluarkan fatwa tentang bolehnya wakaf uang tahun 2002. Peluang yang lebih besar setelah disahkannya rancangan Undang-Undang Wakaf menjadi Undang-Undang Nomor 41 Tahun 2004 Tentang Wakaf. Dengan adanya UndangUndang Wakaf tersebut memberikan harapan kepada semua pihak dalam upaya pemberdayaan ekonomi rakyat, di samping untuk kepentingan peribadatan dan sarana sosial lainnya. Permasalahan pokok dalam paper ini adalah bagaimana potensi wakaf uang di Indonesia dan apa saya yang menjadi strategi dalam pengembangan wakaf uang di Indonesia. Dengan demikian tujuan penelitian ini adalah untuk mendapatkan gambaran potensi wakaf uang di Indonesia dan mendapat gambaran hal- hal apa saja yang menjadi strategi dalam pengembangan wakaf uang di Indonesia dalam upaya pemberdayaan ekonomi umat. Adapun metode yang digunakan dalam tulisan ini merupakan kerangka tulisan hasil pemikiran (library riset). Sebagai lembaga resmi yang ditunjuk pemerintah untuk mensukseskan gerakan wakaf uang di Indonesia, Lembaga Keuangan Syraiah Penerima Wakaf Uang (LKS-PWU) memiliki tanggung jawab yang tidak kecil dalam menentukan sukses tidaknya gerakan wakaf uang di Indonesia. Bersama dengan Badan Wakaf Indonesia (BWI), LKS-PWU dapat melakukan kerja produktif untuk dapat mesukseskan program wakaf uang tersebut. Sejauh ini kerjasama LKS dan BWI yang ada di Indonesia belum berjalan dengan baik. Sehingga kerjasama ini perlu ditingkatkan dalam bentuk yang lebih konkrit dan praktis sehingga gerakan wakaf uang bisa menjangkau sasaran wakif yang lebih luas yang pada gilirannya dapat menggalang dana wakaf uang.
\end{abstract}

Kata Kunci: wakaf uang, wakaf, potensi

\section{PENDAHULUAN}

Wakaf merupakan suatu instrumen keuangan publik dalam Islam yang memiliki peran untuk menciptakan kesejahteraan sosial, yang pada gilirannya dapat meningkatkan perekonomian masyarakat. Ciri utama wakaf yaitu ketika wakaf ditunaikan maka akan terjadi pergeseran kepemilikan pribadi menjadi kepemilikan masyarakat. Wakaf tersebut merupakan dana abadi dan diharapkan dapat memberikan manfaat kepada masyarakat secara berkelanjutan dengan tujuan untuk mengharapkan ridho Allah SWT semata. 
Selama ini wakaf sering sekali diarahkan hanya kepada wakaf benda tidak bergerak seperti tanah, bangunan, pohon untuk diambil buahnya, dan sumur untuk diambil airnya. Sedangkan perbincangan masalah wakaf benda bergerak ramai diperbincangkan baru beberapa tahun terakhir ini. Diantara wakaf benda bergerak yang banyak diperbincangkan adalah wakaf yang dikenal dengan istilah cash waqf, yang diterjemahkan dengan wakaf tunai atau wakaf uang.

Sebagai salah satu instrumen wakaf produktif, wakaf uang merupakan hal yang masih baru di Indonesia. Peluang untuk wakaf uang ada setelah Majelis Ulama Indonesia mengeluarkan fatwa tentang bolehnya wakaf uang tahun 2002. Peluang yang lebih besar setelah disahkannya rancangan Undang-Undang Wakaf menjadi Undang-Undang Nomor 41 Tahun 2004 Tentang Wakaf. Secara terperinci, obyek wakaf di Lembar Negara RI Tahun 2004 Nomor 159 tersebut dijelaskan bahwa harta benda wakaf hanya dapat diwakafkan apabila dimiliki dan dikuasai oleh wakif secara sah (pasal 15). Harta benda wakaf terdiri atas benda tidak bergerak dan benda bergerak. Benda bergerak adalah harta benda yang tidak bisa habis karena dikonsumsi, meliputi: a)Uang; b) Logam mulia; c) Surat berharga; d) Kendaraan; e) Hak atas kekayaan intelektual; f) Hak sewa; dan g) Benda bergerak lain sesuai dengan ketentuan syariah dan peraturan perundang-undangan yang berlaku (pasal 16). Dengan adanya Undang-Undang Wakaf tersebut memberikan harapan kepada semua pihak dalam upaya pemberdayaan ekonomi rakyat, di samping untuk kepentingan peribadatan dan sarana sosial lainnya.

Potensi wakaf uang di Indonesia sangat besar dan dananya dapat digunakan untuk kegiatan ekonomi produktif di samping kegiatan sosial dalam rangka membantu kaum duafa dan kepentingan umat. Sebagai tindak lanjut dari lahirnya Undang-undang Wakaf, beberapa bank syari'ah dan lembaga pengelola wakaf meluncurkan produk dan fasilitas yang menghimpun dana wakaf dari masyarakat. Seperti Baitul Mal Muamalat, meluncurkan Waqaf Tunai Muamalat (Waqtumu), Dompet Dhuafa Republika meluncurkan Tabung Wakaf Indonesia (TWI), dan Pos Keadilan Peduli Umat (PKPU) juga meluncurkan wakaf uang. Lembaga-lembaga ini, sejatinya secara hukum masih terdaftar sebagai lembaga amil zakat. Namun di samping mengelola zakat, lembaga-lembaga ini juga melakukan pengelolaan wakaf uang. Akhir-akhir ini juga Koperasi Jasa Keuangan Syariah (KJKS) atau sering 
dikenal sebagai Baitul Mal wa Tamwil (BMT) sudah mulai melirik untuk mengelola wakaf uang.

Wakaf uang inipun telah menjadi gerakan nasional sejak Presiden Soesilo Bambang Yudhoyono mencanangkan gerakan wakaf uang di Istana Negara pada tanggal 8 Januari 2010. Wakaf telah memfasilitasi keinginan orang untuk berwakaf tanpa menunggu menjadi orang kaya atau mempunyai tanah yang luas. Wakaf uang kemudian dikelola dalam produk keuangan syariah dan sebagian sudah di investasikan langsung kepada sektor riil produktif (M. Cholis Nafis, 2011:48-49).

Ketua Divisi Humas Sosialisasi dan Literasi (Husoli) Badan Wakaf Indonesia (BWI) Atabik Luthfi mengatakan (Republika.co.id, Selasa (16/10) bahwa potensi wakaf uang di Indonesia mencapai Rp. 180 triliun. Kemudian ia menjelaskan dari jumlah Rp.180 triliun itu, sebanyak Rp. 400 miliar sudah terealisasi. Sementara tahun 2019, BWI menargetkan realisasi wakaf tunai mencapai Rp 800 miliar. Salah satu contoh realisasi wakaf uang diperuntukkan membantu mahasiswa berwirausaha dan memenuhi kebutuhan sehari-hari. Program itu disebut Waini atau Wakaf Mahasiswa Indonesia.

Wakaf uang bisa diibaratkan sebagai raksasa yang tertidur. Bila kekuatan raksasa itu dibangunkan, boleh jadi wakaf uang akan menjadi salah satu andalan umat Islam. Apalagi, setiap umat Islam bisa berwakaf uang, tanpa harus menunggu kaya. Hanya dengan uang Rp 10 ribu sekalipun, umat Islam bisa menjadi seseorang wakif. Akan tetapi pada kenyataannya, potensi wakaf uang jauh dari yang diharapakan. Realisasi wakaf uang sebagaimana dalam Laporan Pengelolaan Wakaf Uang Badan Wakaf Indonesia 2011 sebanyak Rp. 2,973,393,876 yang terhimpun selama 5 tahun yaitu dari tahun 2007-2011 oleh 7 Lembaga Keuangan Syariah Penerima Wakaf Uang (LKS-PWU).

Sebagaimana yang diasumsikan oleh Edwin Nasution dan Uswatun Hasanah (2005: 44) tentang potensi wakaf di Indonesia dengan jumlah muslim dermawan diperkirakan sebesar 10 juta jiwa dengan rata-rata penghasilan perbulan Rp. 500 ribu hingga Rp. 10 juta, maka paling tidak akan terkumpul dana sekitar Rp. 3 Trilyun pertahun dari dana wakaf. Seperti perhitungan tabel berikut ini:

\section{Tabel 1. Potensi Wakaf Uang}




\begin{tabular}{lllll}
\hline $\begin{array}{l}\text { Tingkat } \\
\text { penghasilan/bulan }\end{array}$ & $\begin{array}{l}\text { Jumlah } \\
\text { Muslim }\end{array}$ & $\begin{array}{l}\text { Tarif } \\
\text { Wakaf/bulan }\end{array}$ & $\begin{array}{l}\text { Potensi Wakaf } \\
\text { Uang/bulan }\end{array}$ & $\begin{array}{l}\text { Potensi Wang/tahun } \\
\text { Uangar }\end{array}$ \\
\hline Rp. 500.000 & 4 juta & Rp. 5000 & Rp. 20 Milyar & Rp. 240 Milyar \\
Rp. 1 juta - Rp. 2 juta & 3 juta & Rp. 10.000 & Rp. 30 Milyar & Rp. 360 Milyar \\
Rp. 2 juta-Rp. 5 juta & 2 juta & Rp. 50.000 & Rp. 100 Milyar & Rp. 1.2 Triliun \\
Rp. 5 juta- Rp. 10 juta & 1 juta & Rp. 100.000 & Rp. 100 Milyar & Rp. 1.2 Triliun \\
TOTAL & & & & Rp. 3 Triliun \\
\hline
\end{tabular}

Dari ilustrasi di atas disimpulkan bahwa wakaf uang potensial untuk dikembangkan selama bisa dikelola secara optimal. Namun, untuk mengembangkan wakaf uang dan wakaf benda bergerak tentu bukan hal yang mudah. Untuk itu diperlukan usaha sungguh-sungguh yang tidak hanya cukup dilakukan oleh pemerintah dan lembaga wakaf, tetapi perlu melibatkan pihak-pihak lain dari berbagai macam kalangan, seperti ulama, swasta (Nazhir, lembaga keuangan syariah), akademisi, NGO (LSM), dan praktisi atau para ahli di bidang wakaf, untuk memberikan pemahaman dan informasi mengenai wakaf uang, terutama dengan pola pendekatan keagamaan, sehingga hal ini akan mengubah pandangan masyarakat terhadap wakaf uang.

Penelitian yang dilakukan oleh Effendi, dalam tesis nya menyebutkan bahwa walaupun ulama, cendikiawan dan Kiai pesantren mempunyai pengaruh untuk membawa perubahan pemahaman terhadap wakaf uang, penelitian tersebut menyebutkan sebanyak 93\% responden muzakki yang berzakat di BAZNAS dan Dompet Dhu'afa masih menganggap sosialisasi wakaf uang yang dilakukan oleh ulama, Kiai, cendikiawan dan tokoh agama lainnya masih kurang dan belum cukup. Dalam penelitian Efrizon dalam tesis nya yang berjudul faktor-faktor yang mempengaruhi pemahaman masyarakat terhadap wakaf uang menunjukkan bahwa persepsi masyarakat akan wakaf uang dipengaruhi oleh tingkat pendidikan, akses tehadap media informasi, pemahaman hukum Islam, dan keterlibatan dalam organisasi sosial keagamaan yang dilakukan di Kecamatan Rawalumbu Bekasi.

Dari beberapa hasil penelitian di atas dapat dikembangkan kesimpulan bahwa pada hakikatnya wakaf dapat dijadikan sarana/media untuk peningkatan kesejahteraan umat muslim Indonesia bila dikelola secara profesional dan didukung oleh kebijakkan negara dan masyarakat. Pengembangan wakaf produktif memerlukan dukungan yang tidak hanya social driven (bottom up) namun juga diperlukan government Driven (Dukungan pemerintah) sebagaimana dilakukan oleh Malaysia yang terlebih dahulu memiliki sistim pengembangan wakaf yang 
lebih modern dan baik dari pada Indonesia. Permasalahan pokok dalam paper ini adalah bagaimana potensi wakaf uang di Indonesia dan hal apa saya yang menjadi strategi dalam pengembangan wakaf uang di Indonesia? Dengan demikian tujuan penelitian pendahuluan ini adalah untuk mendapatkan gambaran potensi wakaf uang di Indonesia dan mendapat gambaran hal- hal apa saja yang menjadi strategi dalam pengembangan wakaf uang di Indonesia dalam upaya pemberdayaan ekonomi umat.

\section{KERANGKA TEORI}

Kata "Wakaf" atau "Waqf" berasal dari bahasa Arab yaitu kata الوقف (alwaqfu) yang merupakan bentuk masdar dari kata kerja وقف (waqafa). Kata kerja ini dalam bahasa Indonesia berarti seseorang berhenti dari berjalan. Secara etimologi, wakaf adalah al-habs (menahan). Kata (وقف يقف - وققا) sama artinya dengan - حبس ) (al-Habs) adalah bentuk masdar yang bermakna menahan, berhenti, atau diam (Abdul Qodir, 2011: 25). Dalam Kamus Al-Munawwir disebutkan bahwa kata وقف gerarti berhenti, berdiri dan mencegah. Yang dimaksud dengan wakaf adalah, "Tahbiisul ashl wa tassbhiilul manfa'ah," yaitu menahan suatu barang dan memberikan manfaatnya (Syaikh Muhammad bin Shalih al'Utsaimin, 2008:5).

Tashbiisul Ashl, yaitu menahan barang, yaitu jenis barang seperti: rumah, tanah, pohon, dan mobil serta yang serupa dengannya. Sebab, wakaf bisa berupa barang-barang yang bergerak ataupun yang tetap. Sedangkan, Tashbiilul manfa'ah yaitu memberikan manfaatnya yaitu melepaskannya. Maksud dari pengertian di atas adalah orang yang berwakaf menahan barang tersebut dari segala hal yang dapat mengalihkan kepemilikan dan orang tersebut memberikan manfaatnya. Para ulama berbeda pendapat tentang arti wakaf secara istilah (hukum). Mereka mendefenisikan wakaf dengan defenisi yang beragam, sesuai dengan perbedaan mazhab yang mereka anut, baik dari segi kelaziman dan ketidaklazimannya, syarat pendekatan di dalam masalah wakaf ataupun posisi pemilik harta benda wakaf seteleh diwakafkan. 
Wakaf Tunai (cash waqf) sudah dipraktekkan sejak awal abad kedua hijriyah. Imam az Zuhri (wafat $124 \mathrm{H}$ ) salah seorang ulama terkemuka dan peletak dasar tadwin al hadits memfatwakan, dianjurkan wakaf dinar dan dirham untuk pembangunan sarana dakwah, sosial, dan pendidikan umat Islam. Adapun caranya adalah dengan menjadikan uang tersebut sebagai modal usaha kemudian menyalurkan keuntungannya sebagai wakaf. Beberapa manfaat utama wakaf tunai antara lain adalah: a) Seseorang yang memiliki dana terbatas sudah bisa mulai memberikan dana wakafnya tanpa harus menunggu menjadi tuan tanah terlebih dahulu. b) Melalui wakaf uang, aset-aset wakaf yang berupa tanah-tanah kosong bisa mulai dimanfaatkan dengan pembangunan gedung atau diolah untuk lahan pertanian. c) Dana wakaf tunai juga bisa membantu sebagian lembaga-lembaga pendidikan Islam. d) Umat Islam dapat lebih mandiri dalam mengembangkan dunia pendidikan tanpa harus terlalu tergantung pada anggaran pendidikan negara yang memang semakin lama semakin terbatas.

\section{Pengertian Wakaf Uang}

Munculnya pemikiran wakaf uang/tunai yang dipelopori oleh Prof. Dr. M.A. Mannan, seorang ekonom yang berasal dari Bangladesh pada dekade ini merupakan momen yang sangat tepat untuk mengembangkan instrumen wakaf untuk membangun kesejahteraan umat. Sebelum Undang-Undang Nomor 41 Tahun 2004 tentang Wakaf ada, Pada tanggal 11 Mei 2002 Majelis Ulama Indonesia (MUI) telah mengeluarkan fatwa yang membolehkan wakaf uang (cash wakaf/ waqf al nuqud) dengan syarat nilai pokok wakaf harus dijamin kelestariannya. Pengertian wakaf sebagaimana tersebut dalam Pasal 1 Undang- Undang Nomor 41 Tahun 2004 tentang Wakaf, diperluas lagi berkaitan dengan Harta Benda Wakaf (obyek wakaf) yang diatur dalam Pasal 16 yaitu: (1) Harta Benda Wakaf terdiri dari: (a) benda tidak bergerak; dan (b) benda bergerak; (2) Benda tidak bergerak sebagaimana dimaksud pada ayat (1) huruf (a) meliputi: hak atas tanah sesuai dengan ketentuan perundang-undangan yang berlaku, baik yang sudah maupun yang belum terdaftar; bangunan atau bagian bangunan yang berdiri di atas tanah sebagaimana dimaksud pada huruf a; tanaman dan benda lain yang berkaitan dengan tanah; hak milik atas satuan rumah susun sesuai dengan ketentuan peraturan perundang-undangan yang berlaku; benda tidak bergerak lain sesuai dengan ketentuan syariah dan peraturan perundang-undangan yang berlaku; (3) Benda bergerak sebagaimana dimaksud pada Ayat (1) Huruf b adalah 
harta benda yang tidak bisa habis karena dikonsumsi, meliputi Uang; logam mulia; surat berharga; kendaraan; hak atas kekayaan intelektual; hak sewa, dan benda bergerak lain sesuai dengan ketentuan syariah dan peraturan perundang-undangan yang berlaku (Kementerian Agama RI, 2011: 8-9).

Dengan demikian yang dimaksud wakaf uang/tunai adalah wakaf yang dilakukan seseorang, kelompok orang dan lembaga atau badan hukum dalam bentuk tunai. Juga termasuk kedalam pengertian uang adalah surat-surat berharga, seperti saham, cek dan lainnya. Selain hal itu, Majelis Ulama Indonesia (MUI) telah mengeluarkan Fatwa tentang Wakaf Uang pada tanggal 11 Mei 2002, yang menyatakan bahwa : (1) wakaf Uang (Cash Wakaf/Waqfal-Nuqud) adalah wakaf yang dilakukan seseorang, kelompok orang, lembaga atau badan hukum dalam bentuk tunai; (2) termasuk ke dalam pengertian uang adalah surat berharga; (3) wakaf Uang hukumnya jawaz (boleh); (4) wakaf Uang hanya boleh disalurkan dan digunakan untuk hal-hal yang diperbolehkan secara syar'i; (5) nilai pokok Wakaf Uang harus dijamin kelestariannya, tidak boleh dijual, dihibahkan dan/atau diwariskan.

\section{Potensi Wakaf Uang}

Seluruh program pengentasan kemiskinan yang telah dilaksanakan oleh pemerintah dengan tujuan untuk memberdayakan masyarakat masih belum mampu memperlihatkan hasil yang signifikan di masyarakat. Hal ini menandakan bahwa program pemberdayaan masyarakat masih membutuhkan dukungan dari sub-sistem lain. Dukungan dari sub-sistem selain pemerintah sangat dibutuhkan agar manfaat pemberdayaan masyarakat dapat semakin berdayaguna dalam meningkatkan kemaslahatan masyarakat. Salah satu sub-sistem yang dapat mendukung program pemberdayaan masyarakat yang dilaksanakan oleh pemerintah adalah dengan mengoptimalkan sumber-sumber keuangan Islam termasuk wakaf.

Praktik ijtihad yang telah berkembang pada saat ini dalam pendayagunaan wakaf adalah wakaf uang. Penerapan wakaf uang pada masa sekarang, akan mempunyai keunggulan yang lebih besar dari wakaf tradisional, yaitu benda bergerak atau tidak bergerak. Identik di masyarakat apabila terkait dengan harta wakaf, maka akan langsung dihubungkan dengan sarana ibadah, sarana pendidikan, sarana kesehatan serta makam. Secara umum, wakaf benda bergerak atau tidak bergerak hanya dapat dilakukan oleh orang yang memiliki harta lebih. Hal inilah 
yang menyebabkan kekayaan wakaf di Indonesia masih sedikit. Selain karena jumlah harta wakaf yang masih sedikit, pengelolaannya pun masih belum menerapkan manajemen modern.

Sebagai salah satu instrument fiskal Islam yang telah ada semenjak awal kedatangan Islam. Fakta sejarah memperlihatkan bahwa wakaf telah menunjukkan berbagai peran penting dalam mengembangkan berbagai kegiatan sosial, ekonomi, pendidikan dan kebudayaan. Wakaf harus mampu berperan efektif dalam membangun umat, agar mampu mengurangi ketergantungan pendanaan dari pemerintah. Wakaf terbukti mampu menjadi instrument jaminan sosial dalam pemberdayaan masyarakat. Berdasarkan definisi wakaf yang terdapat dalam Undang-undang mengakomodir berbagai macam harta benda wakaf termasuk adalah wakaf uang.

Secara spesifik, undang-undang tersebut memuat bagian tentang wakaf uang, dimana dalam pasal 28 sampai pasal 31 ialah wakaf uang harus disetor melalui Lembaga Keuangan Syariah (LKS) yang telah ditetapkan oleh Menteri Agama RI. Wakaf uang harus dibuktikan dengan sertifikat. Dalam Peraturan Badan Wakaf Indonesia No. 01 tahun 2009 tentang Pedoman Pengelolaan dan Pengembangan Harta Benda Wakaf Bergerak berupa Uang, sertifikat dapat diberikan kepada wakif yang telah mewakafkan uangnya paling sedikit Rp.1.000.000 (satu juta rupiah) dengan menyertakan asal-usul uang dan identitas lengkap wakifnya. Jumlah umat Islam yang terbesar di dunia terutama di Indonesia merupaka aset terbesar untuk penghimpunan dan pengembangan wakaf uang. Jika wakaf uang dapat diimplementasikan maka akan terdapat dana potensial yang dapat dipergunakan bagi kemaslahatan umat (Jurnal Dialog Balitbang Kemenag RI, 2010: 4).

\section{Sertifikat Wakaf Tunai}

Wakaf tunai dapat digunakan sebagai suatu instrumen keuangan dan merupakan produk baru dalam sektor perbankan. Beberapa pedoman operasional Sertifikat Wakaf Tunai yang dipraktekkan Social Investment Bank Ltd (SIBL) antara lain: a) wakaf tunai harus dipandang sebagai sumbangan (endowment) yang sesuai dengan syariah, bank akan 
mengelola wakaf atas nama wakif; b) wakaf dapat diberikan berulang kali dan rekening yang dibuka sesuai dengan nama yang diberikan wakif; c) wakif diberi kebebasan untuk memilih sasaran wakaf baik sasaran yang sudah terindentifikasi oleh SIBL atau sasaran lainnya yang sesuai dengan syariah. Aantara lain : Rehabilitasi Keluarga(Family Rehabilitation), Pendidikan dan kebudayaan (Education and Culture), Kesehatan dan Sanitasi (Health and Sanitation) dan Pelayanan Sosial (Social Utility Service); d) dana wakaf tunai akan mendapat keuntungan pada tingkat yang yang paling tinggi yang ditawarkan oleh bank dari waktu kewaktu; e) dana wakaf akan tetap dan hanya dana yang berasal dari keuntungan yang akan dibagikan kepada sasaran yang telah dipilih wakif. Keuntungan yang belum sempat dibagikan otomatis akan digabungkan dengan dana wakaf yang sudah ada yang akan mendapatkan keuntungan yang lebih berkembang sepanjang waktu; f) wakif juga dapat meminta bank untuk menyalurkan seluruh keuntungan yang diperoleh kepada sasaran yang telah ditentukan oleh wakif; g) wakif mempunyai kesempatan memberikan wakaf tunai sepanjang waktu. Walaupun tidak, wakif akan memberikan wakaf sebesar yang dia inginkan dan akan mulai dengan nilai minimum wakaf sebesar TK 1000. Wakaf berikutnya akan sebesar TK 1000 pula atau kelipatannya; h) wakif mempunyai hak untuk memberikan perintah pada bank untuk mengambil dana wakaf dari rekening lainnya di SIBL secara rutin; i) wakaf tunai harus diterima dalam bentuk endowment receipth voucher tertentu dan satu sertifikat untuk seluruh nilai harus diterbitkan ketika wakaf tersebut diberikan; j) prinsip dan ketentuan mengenai Rekening Wakaf Tunai berdasarkan amandemen dan akan dievaluasi dari waktu ke waktu.

\section{METODOLOGI}

Adapun metode yang digunakan dalam tulisan ini merupakan kerangka tulisan hasil pemikiran (library riset). Menjelaskan secara deskriptif dan menganalisis tentang konsep wakaf uang, potensi wakaf uang, dan menjelaskan strategi pengembangan wakaf uang di Indonesia. Untuk mendapatkan fakta dan penafsiran yang tepat maka pendekatan yang digunakan deskriftip-kualitatif yang lebih menekankan analisisnya pada proses penyimpulan deduktif dan induktif dan melakukan analisis hanya sampai pada taraf deskripsi. Wawancara dilakukan untuk mendapatkan informasi strategi yang dilakukan dalam mengembangkan wakaf uang. 


\section{PEMBAHASAN}

\section{Potensi Wakaf Uang di Indonesia}

Indonesia adalah negara yang memiliki jumlah penduduk Muslim terbesar di seluruh dunia. Pada saat ini diperkirakan bahwa jumlah umat Muslim Indonesia mencapai 207 juta orang. Jumlah umat Islam yang besar tersebut merupakan suatu potensi yang besar pula terhadap pengumpulan dana wakaf uang di Indonesia. Jika diasumsikan tentang potensi wakaf di Indonesia dengan jumlah muslim dermawan diperkirakan hanya sekitar 50 juta jiwa dengan rata-rata penghasilan perbulan Rp. 500 ribu hingga Rp. 10 juta, maka paling tidak akan terkumpul dana sekitar Rp. 15 Trilyun pertahun dari dana wakaf. Seperti perhitungan tabel berikut ini:

\section{Tabel 2. Potensi Wakaf Uang di Indonesia}

\begin{tabular}{|c|c|c|c|c|}
\hline $\begin{array}{l}\text { Tingkat } \\
\text { penghasilan/bulan }\end{array}$ & $\begin{array}{l}\text { Jumlah } \\
\text { Muslim }\end{array}$ & $\begin{array}{l}\text { Tarif } \\
\text { Wakaf/bulan }\end{array}$ & $\begin{array}{l}\text { Potensi Wakaf } \\
\text { Uang/bulan }\end{array}$ & $\begin{array}{l}\text { Potensi Wakaf } \\
\text { Uang/tahun }\end{array}$ \\
\hline Rp. 500.000 & 20 juta & Rp. 5000 & Rp. 100 Milyar & Rp. 1.2 Triliun \\
\hline Rp. 1 juta - Rp. 2 juta & 15 juta & Rp. 10.000 & Rp. 150 Milyar & Rp. 1.8 Triliun \\
\hline Rp. 2 juta - Rp. 5 juta & 10 juta & Rp. 50.000 & Rp. 500 Milyar & Rp. 6 Triliun \\
\hline $\begin{array}{l}\text { Rp. } 5 \text { juta- Rp. } 10 \text { juta } \\
\text { TOTAL }\end{array}$ & 5 juta & Rp. 100.000 & Rp. 500 Milyar & $\begin{array}{l}\text { Rp. } 6 \text { Triliun } \\
\text { Rp. } 15 \text { Triliun }\end{array}$ \\
\hline
\end{tabular}

Sumber: Data Olahan

Dari gambaran pada tabel di atas disimpulkan bahwa, jika sekitar 50 juta umat Islam saja yang berwakaf uang sudah bisa terkumpul dana sebesar 15 triliun pertahunnya. Dana tersebut akan bisa ditingkatkan lagi jika pengelolaannya dilakukan secara optimal. Akan bertambah lebih besar lagi jika 50\% umat Islam di Indonesia memiliki jiwa kedermawanan dan mewakafkan uangnya, maka akan terkumpul dana sekitar 30 triliun pertahunnya.

Lembaga Wakaf Majelis Ulama Indonesia (MUI) menilai potensi wakaf di Indonesia sangat besar, apalagi 85\% masyarakat Indonesia adalah muslim. Lebih lanjut, laporan menunjukkan potensi aset wakaf tunai per tahun mencapai lebih dari Rp100 triliun, dengan realisasi sekitar Rp 400 miliar di tahun 2018. Data terakhir menunjukkan bahwa potensi wakaf di Indonesia mencapai Rp300 triliun dengan realisasi yang baru mencapai sekitar Rp500 miliar. Masih besarnya potensi yang belum tergarap ini, salah satunya disebabkan oleh kurangnya pemahaman masyarakat. Untuk itu, seluruh pihak perlu bekerja sama melakukan edukasi dan sosialisasi agar potensi ini dapat dioptimalkan. Saat ini dari ribuan Sahabat Wakaf 
yang dimiliki oleh MUI, 102 orang Sahabat Wakaf telah tersertifikasi. (Ketua Lembaga Wakaf MUI Lukmanul Hakim di Jakarta, Selasa (7/5/2019).

\section{Pengelolaan Wakaf Uang di Indonesia}

Pengelolaan wakaf tunai/ uang di Indonesia dikelompokkan menjadi dua yaitu wakaf tunai dikelola Bank Syariah dan Lembaga Swasta, a) wakaf tunai dikelola Bank Syariah. Beberapa peran yang bisa diunggulkan bila wakaf tunai dikelola oleh bank: jaringan kantor, kemampuan sebagai fund manager, pengalaman, jaringan informasi dan peta distribusi, dan citra positif. Bank syariah hanya sebagai nadzir penerima dan penyalur. Sedangkan fungsi pengelola dana akan dilakukan oleh lembaga lain, misalnya Badan Wakaf Tunai (BWN), yang dengan sendirinya tanggungjawab pengelolaan dana, termasuk hubungan kerja sama dengan lembaga penjamin berada pada BWN, b) wakaf tunai dikelola lembaga swasta. Keunggulan yang di dapat bila wakaf tunai dikelola oleh swasta adalah; sesuai dengan kebutuhan riil masyarakat, ada kontrol langsung oleh masyarakat, menumbuhkan solidaritas masyarakat.

Skema alternatif bila bank syariah sebagai nadzir penerima dan penyalur dana wakaf.

Gambar 1. Bank sebagai Penerima dan Penyalur

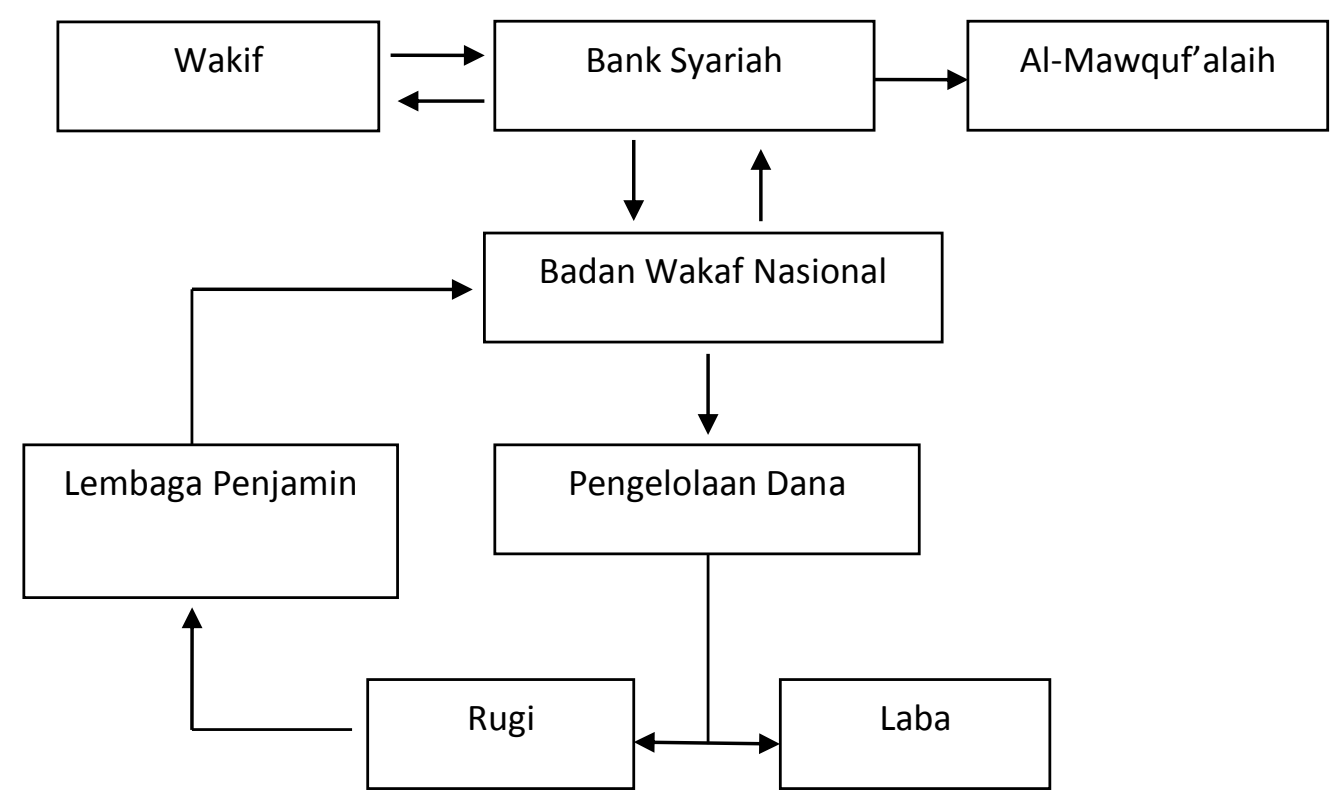

Sumber: Heri Sudarsono, 2004: 269. 
Lembaga swasta ini misalnya bergerak dibidang pendidikan, dapat dibuat skema sebagai berikut:

Gambar 2. Lembaga sebagai Penerima dan Penyalur

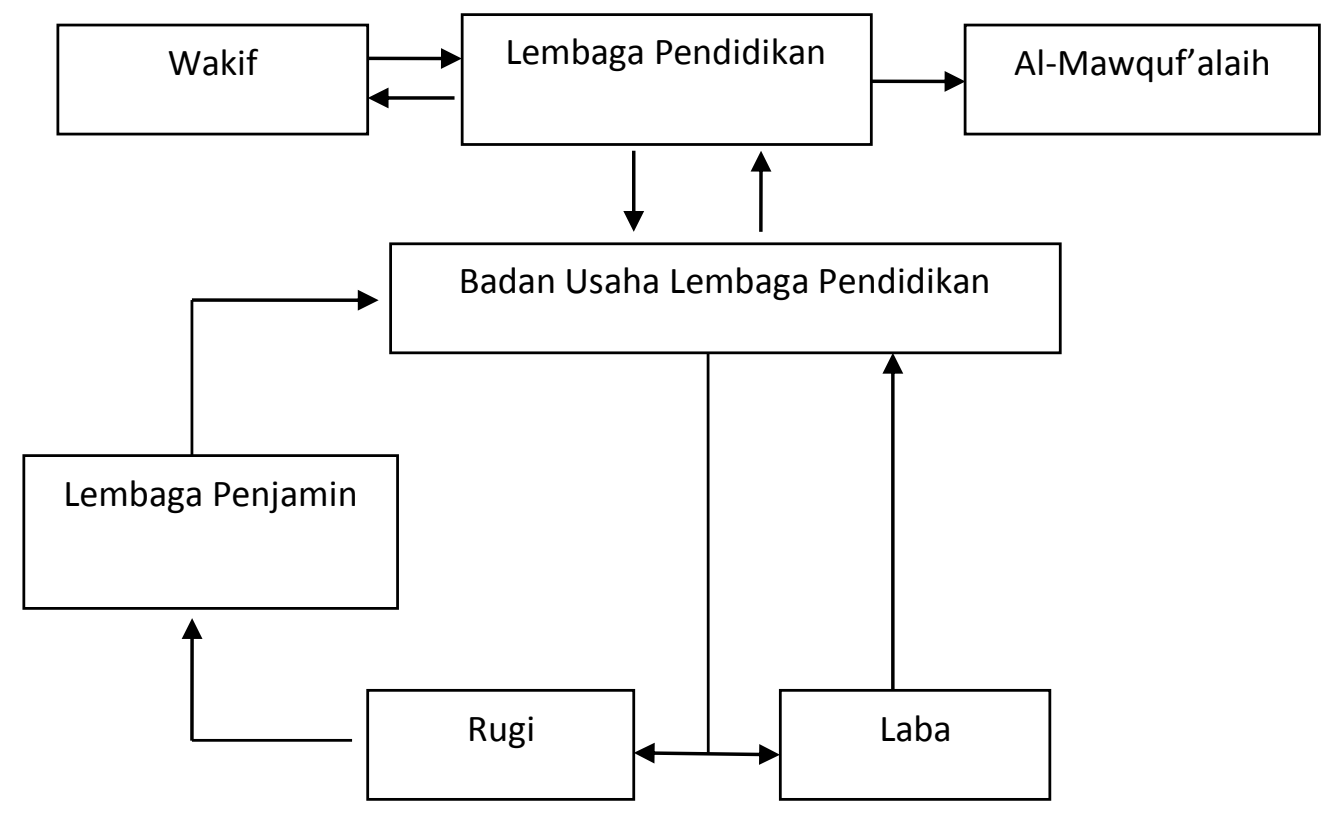

Sumber: Heri Sudarsono, 2004: 270

Lembaga pendidikan swasta mengelola sendiri dana yang diterima muwakif dengan sistem musyarakah atau mudlarabah tanpa mengurangi nilai aset wakaf. Selanjutnya, keuntungan yang diterima di dasarkan atas sistem bagi hasil diatas, diterima oleh lembaga pendidikan sebagai keuntungan usaha dan diterima wakaf tunai sebagai tambahan aset. Dari tambahan aset wakaf tunai tersebut bisa digunakan membantu masyarakat dalam bentuk wakaf pula.

\section{Kendala Pengembangan Wakaf Uang}

Beberapa kendala menjadikan wakaf tunai sulit berkembang di tanah air adalah sebagai berikut: a) masyarakat masih memahami bahwa wakaf berhubungan dengan hartaharta yang memiliki nilai tinggi seperti tanah, rumah, dan lain sebagainya; b) wakaf tunai relatif baru di Indonesia, sehingga dampak langsung dari kelebihan wakaf tunai bagi kesejahteraan masyarakat belum terasa; c) lembaga wakaf tunai masih difahami sebagai lembaga zakat, dan lembaga zakat bisa dijadikan pengganti keberadaan lembaga wakaf tunai. Hal ini yang menjadikan keberadaan lembaga wakaf tunai terasa tidak begitu urgent; 
d) tidak ada konsekuensi hukum yang mengikat kepada individu untuk mewakafkan sebagian hartanya.

\section{Strategi Pengembangan Wakaf Uang di Indonesia}

Usaha yang perlu dilakukan untuk mengurangi kendala-kendala diatas adalah: a) sosialisasi keberadaan wakaf tunai kepada masyarakat, bahwa masyarakat tidak perlu menunggu sampai jumlah tertentu hartanya guna membeli sejumlah harta untuk diwakafkan. Wakaf bisa dilakukan dengan cash, walaupun ia tidak memiliki harta, seperti tanah, rumah, dan lain sebagainya; b) mendirikan lembaga wakaf tunai dapat dimulai dari lingkungan terkecil seperti, takmir mesjid, pesantren dan sebagainya. Pendirian lembaga wakaf tunai tidak harus menunggu kelompok/ institusi, selama individu/ sekelompok individu mampu mendirikannya maka tidak ada halangan untuk mendirikan lembaga wakaf tunai; c) perlu koordinasi dengan lembaga zakat untuk menjalin kerja sama dan meningkatkan kinerja antara kedua lembaga tersebut, dengan tujuan untuk mensejahterakan masyarakat.

Sebagai lembaga resmi yang ditunjuk pemerintah untuk mensukseskan gerakan wakaf uang di Indonesia, Lembaga Keuangan Syraiah Penerima Wakaf Uang (LKS-PWU) memiliki tanggung jawab yang tidak kecil dalam menentukan sukses tidaknya gerakan wakaf uang di Indonesia. Sesuai dengan Undang-undang, LKS-PWU diberi mandat oleh pemerintah salah satunya adalah untuk mengumumkan kepada publik atas keberadaannya sebagai LKS Penerima Wakaf Uang, sebagaimana dalam PP No. 442 Tahun 2006 dan UU No. 41 Tahun 2004, Pasal 25. Tugas ini tentu saja tidak hanya sebatas pada pemberitahuan lembaga ini sebagai penerima wakaf, tetapi juga memberikan tanggungjawab untuk memasyarakatkan wakaf uang kepada masyarakat secara lebih luas melalui sarana dan strategi yang efektif.

Bersama dengan Badan Wakaf Indonesia (BWI), LKS-PWU dapat melakukan kerja produktif untuk dapat mesukseskan program wakaf uang tersebut. Sejauh ini kerjasama LKS dan BWI yang ada di Indonesia belum berjalan dengan baik. Sehingga kerjasama ini perlu ditingkatkan dalam bentuk yang lebih konkrit dan praktis sehingga gerakan wakaf uang bisa menjangkau sasaran wakif yang lebih luas yang pada gilirannya dapat menggalang dana wakaf uang. 
Langkah-Langkah ataupun strategi dalam mengembangkan potensi wakaf Uang yang perlu dilakukan adalah:

Pertama, Menyamakan pemahaman terhadap Undang-Undang tentang wakaf serta aturan pelaksanaannya antara Kemenag RI, BWI dengan lembaga Keuangan Syariah Penerima Wakaf Uang (LKS-PWU). Dengan tujuan agar masing-masing lembaga memahami tugasnya dengan jelas. Sebagai lembaga-lembaga yang sangat berperan dalam memberikan pemahaman kepada masyarakat mengenai wakaf uang, belum terlihat adanya langkah nyata yang ditempuh dalam rangka sosialisasi wakaf uang kepada masyarakat. Hal ini menuntut pentingnya adannya pertemuan antara ke tiga lembaga tersebut. Beberapa kemungkinan alasan yang menyebabkan kondisi tersebut adalah adanya penghematan anggaran dari pemerintah, sehingga anggaran untuk mengadakan yang sifatnya orientasi, pelatihan, seminar mengenai wakaf uang ini belum bisa berjalan, kemudian kondisi politik di negara kita sekarang ini, sehingga masalah-masalah prioritas yang harus segera mendapat perhatian, sementara yang sifatnya anjuran-anjuran kurang mendapat perhatian pemerintah.

Kedua, Pada pembahasan mengenai persepsi masyarakat, menunjukkan bahwa persepsi masyarakat dapat mempengaruhi potensi wakaf uang. Hal ini dilihat dari kebanyakan masyarakat mengetahui wakaf adalah berupa benda tidak bergerak seperti tanah, kendaraan, dan bangunan, sehingga ketika dianjurkan untuk berwakaf, mereka menyatakan ketidakmampuannya karena tidak memiliki tanah atau bangunan yang akan di wakafkan. Beberapa upaya dalam memberikan pemahaman kepada masyarakat mengenai wakaf uang ini sudah pernah dilakukan sebelumnya oleh Kementerian Agama diantaranya yaitu: 1) adanya penyuluhan wakaf yang dilakukan oleh pejabat Kementerian Agama yang berada pada Direktorat Pemberdayaan Wakaf. 2) kemenag meminta kepada lembaga dakwah agar memasukkan materi dakwahnya mengenai wakaf khususnya wakaf uang, dalam rangka memberikan pemahaman kepada masyarakat mengenai wakaf uang; 3) kemenag memberi pelatihan-pelatihan kepada para lembaga/ pengelola wakaf untuk meningkatkan profesionalisme para pengelola wakaf, dan para pengelola / nadzir ini juga diharapkan untuk memberikan penjelasan kepada masyarkat yang ingin berwakaf/ calon wakif mengenai wakaf uang; 4) kemenag melakukan sosialisasi wakaf melalui kertas-kertas selebaran, dan media elektronik. Rencana 
ke depan juga akan dilakukan oleh BWI Propinsi Riau dengan program yang lebih efektif dalam memberikan pemahaman mengenai wakaf uang kepada masyarakat dengan pendekatan bahasa yang mudah untuk di cerna oleh masyarakat awam, bahkan anak-anak sekalipun bisa memahami wakaf uang itu dengan membuat semacam tulisan dalam bentuk komik atau cerpen dengan cerita dan bahasa yang menarik, dan mudah di mengerti. Sehingga harapan wakaf uang menjadi sesuatu yang akrab dengan masyarakat akan dapat dicapai.

Ketiga, Minimnya nadzir wakaf uang, LKS-PWU dan BWI Propinsi Riau lebih proaktif untuk mencari nazdir yang potensial, karena dengan nadzir yang sudah tersertifikasi akan sangat potensial dalam meningkatkan peran mereka dalam menggalang wakaf uang dari masyarakat. Dalam hal mencari nadzir yang potensial ini, dilakukan dengan: 1) adanya kerja sama di kalangan para da'i, LKS- PWU, BWI dan lembaga-lembaga wakaf lainnya; 2) memberi pelatihan-pelatihan kepada para lembaga/ pengelola wakaf untuk meningkatkan profesionalisme para pengelola wakaf, baik lembaga-lembaga pengelola wakaf swasta maupun lembagalembaga pengelola wakaf milik pemerintah daerah.

Keempat, yang diharapkan dalam tugas ini adalah para dosen yang mengajar mata kuliah wakaf, atau para sarjana, khususnya Magister (S2) dan doktor (S3) yang pernah meneliti tentang wakaf. (Wawancara dengan Irhas: Kepala Bidang Urusan Agama Islam Kemenag Propinsi Riau tangal 7 April 2015). Dengan program ini, informasi mengenai wakaf uang yang disampaikan kepada masyarakat akan sampai kepada masyarakat dengan mendapatkan ilmu yang sebenarnya mengenai wakaf uang.

\section{KESIMPULAN}

Potensi wakaf uang di Indonesia sangat besar dan dananya dapat digunakan untuk kegiatan ekonomi produktif di samping kegiatan sosial dalam rangka membantu kaum duafa dan kepentingan umat. Sebagai tindak lanjut dari lahirnya Undang-undang Wakaf, beberapa bank syari'ah dan lembaga pengelola wakaf meluncurkan produk dan fasilitas yang menghimpun dana wakaf dari masyarakat. Seperti Baitul Mal Muamalat, meluncurkan Waqaf Tunai Muamalat (Waqtumu), 
Dompet Dhuafa Republika meluncurkan Tabung Wakaf Indonesia (TWI), dan Pos Keadilan Peduli Umat (PKPU) juga meluncurkan wakaf uang. Lembaga-lembaga ini, sejatinya secara hukum masih terdaftar sebagai lembaga amil zakat. Namun di samping mengelola zakat, lembaga-lembaga ini juga melakukan pengelolaan wakaf uang. Lembaga Wakaf Majelis Ulama Indonesia (MUI) menilai potensi wakaf di Indonesia sangat besar, apalagi 85\% masyarakat Indonesia adalah muslim. Lebih lanjut, laporan menunjukkan potensi aset wakaf tunai per tahun mencapai lebih dari Rp100 triliun, dengan realisasi sekitar Rp 400 miliar di tahun 2018. Data terakhir menunjukkan bahwa potensi wakaf di Indonesia mencapai Rp300 triliun dengan realisasi yang baru mencapai sekitar Rp500 miliar. Masih besarnya potensi yang belum tergarap ini, salah satunya disebabkan oleh kurangnya pemahaman masyarakat. Untuk itu, seluruh pihak perlu bekerja sama melakukan edukasi dan sosialisasi agar potensi ini dapat dioptimalkan. Saat ini dari ribuan Sahabat Wakaf yang dimiliki oleh MUI, 102 orang Sahabat Wakaf telah tersertifikasi.

Langkah-Langkah ataupun strategi dalam mengembangkan potensi wakaf uang di Indonesia yang perlu dilakukan diantaranya: Pertama, Menyamakan pemahaman terhadap Undang-Undang tentang wakaf serta aturan pelaksanaannya antara Kemenag RI, BWI dengan lembaga Keuangan Syariah Penerima Wakaf Uang (LKS-PWU) Kedua, Minimnya nadzir wakaf uang, LKS-PWU dan BWI Propinsi Riau lebih proaktif untuk mencari nazdir yang potensial, karena dengan nadzir yang sudah tersertifikasi akan sangat potensial dalam meningkatkan peran mereka dalam menggalang wakaf uang dari masyarakat. Ketiga, yang diharapkan dalam tugas ini adalah para dosen yang mengajar mata kuliah wakaf, atau para sarjana, khususnya Magister (S2) dan doktor (S3) yang pernah meneliti tentang wakaf. Dengan program ini, informasi mengenai wakaf uang yang disampaikan kepada masyarakat akan sampai kepada masyarakat dengan mendapatkan ilmu yang sebenarnya mengenai wakaf uang.

\section{DAFTAR PUSTAKA}

Alaidin, dkk, ksplorasi Praktik Hukum Islam Wakaf Produktif dan Akuntabilitas Lembaga-Lembaga Wakaf di Indonesia, Pekanbaru: LPPM UIN SUSKA RIAU, 2018,

Al-'Utsaimin Syaikh Muhammad bin Shalih, Panduan Wakaf, Hibah, dan Wasiat, Terj. Abu Hudzaifah, Jakarta: Pustaka Imam Asy-Syafi'i, 2008 
Direktorat Jenderal Bimbingan Masyarakat Islam Direktorat Pemberdayaan Wakaf, Himpunan Peraturan Perundang-Undangan Tentang Wakaf, Jakarta: Kementerian Agama RI, 2011

Edwin Nasution, Mustafa dan Uswatun Hasanah, Tunai - Inovasi Finansial Islam, Peluang dan Tantangan Dalam Mewujudkan Kesejahteraan Umat, Pusat Kajian Timur Tengah dan Islam,Universitas Indonesia bekerja sama dengan Bank Indonesia, didukung oleh Departemen Agama RI, Jakarta, 2005

Effendy, Muhammad Ilham, Tesis Faktor-Faktor yang Mempengaruhi Persepsi Para Muzakki BAZNAS- Dompet Dhu'afa untuk Berwakaf Melalui Wakaf Tunai, Univertsitas Indonesia, 2007.

Efrizon, A., Tesis Faktor-Faktor yang Mempengaruhi Pemahaman Masyarakat terhadap Wakaf Uang, Universitas Indonesia, 2008.

Irhas:_Kepala Bidang Urusan Agama Islam Kemenag Propinsi Riau merangkap sebagai Sekretaris BWI Propinsi Riau, (wawancara), pada tangal 7 April 2015.

Jurnal Dialog Balitbang Kemenag RI No. 70, Tahun XXXIII, 2010

Muhammad, Metodologi Penelitian Ekonomi Islam, PT Raja Grafindo Persada, Jakarta, 2008

Nafis , M. Cholis, Al-Awqaf: Aplikasi Wakaf Uang di Indonesia, Jakarta: Badan Wakaf Indonesia, 2011

Qodir, Abdul, Al-Awqaf: Wakaf dan Praktik Istibdal Tanah Wakaf di Indonesia, Jakarta: Badan Wakaf Indonesia, Volume IV, Nomor 02 Juli 2011

Saifudin Aswar,Metode Penelitian, Pustaka Pelajar Offset, Yogyakarta, 1998

Satori, Djam'an, dan Aan Komariah, Metodologi Penelitian Kualitatif, Bandung: Alpabeta, 2011

Sudarsono „Heri, Bank dan Lembaga Keuangan Syari'ah Deskripsi dan Ilustrasi, Yogyakarta: Ekonisia, 2004

Suhendi, Hendi, Fiqh Muamalah, (Jakarta: PT. Raja Grafindo Persada), 2011

Laporan Pengelolaan Wakaf Uang Badan Wakaf Indonesia 2011

www.bwi.or.id

www.wartaekonomi.co.id diakses 31 Maret 2010 